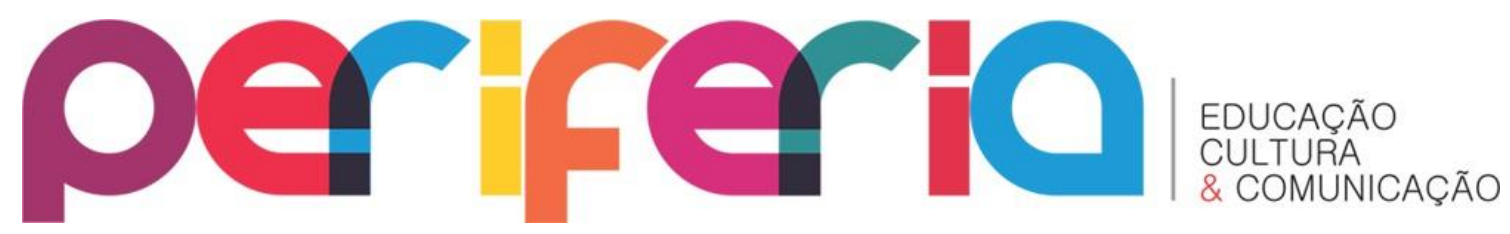

\title{
INDÚSTRIA CULTURAL E CIBERCULTURA - APROXIMAÇÕES E DISTANCIAMENTOS DE CONCEITOS E PRÁTICAS NA CONTEMPORANEIDADE
}

\author{
Marcus Alexandre de Pádua Cavalcanti ${ }^{1}$ \\ Unigranrio
}

\section{RESUMO}

O presente artigo propõe uma reflexão sobre as relações e os processos de comunicação promovidos pelas redes digitais e os meios de comunicação de massas, no sentido de perceber, na contemporaneidade, como ambos se integram e se complementam em suas práticas. No decorrer desta apresentação, serão abordados os conceitos de indústria cultural, cibercultura, hegemonia, contra-hegemonia e rizoma. Tais conceitos serão utilizados para analisar e apontar as dinâmicas e configurações das formas verticais/centralizadas e horizontais/descentralizadas de comunicação. As metáforas das ramificações arborescentes e rizomáticas serão utilizadas nesse contexto para visualizar e comunicar melhor o funcionamento desses dois sistemas. Discutem-se as características desses dois paradigmas, como eles convivem e se agenciam de maneira colaborativa e concomitante, potencializando e ampliando as práticas comunicacionais.

Palavras-chave: indústria cultural, hegemonia, contra-hegemonia, cibercultura.

\section{CULTURAL INDUSTRY AND CYBERCULTURE - APPROACHES AND CONCEPTS AND PRACTICES IN CONTEMPORARY DISTANCES ABSTRACT}

This paper proposes a reflection on the relationships and communication processes promoted by digital networks and the means of mass communication, to realize, in contemporary times, as both complement and integrate into their practices. During this presentation, we will focus on concepts of cultural industry, cyberculture, hegemony, counter-hegemony and rhizome. These concepts will be used to analyze and point out the dynamics and configurations of the vertical/horizontal and centralized/decentralized forms of communication. The metaphors of arborescent and rhizomatic ramifications will be used in this context to better communicate and visualize the functioning of these two systems. Discusses the characteristics of these two paradigms, how they coexist and tout collaboratively and concurrently, enhancing and expanding the communication practices.

Keywords: cultural industry, hegemony, counter-hegemony, cybercultura.

\footnotetext{
${ }^{1}$ Graduado e especialista em Filosofia, mestrando do Programa de Pós-Graduação em Letras e Ciências Humanas da Unigranrio. Bolsista da Capes. E-mail: marcus nathan1203@hotmail.com
} 


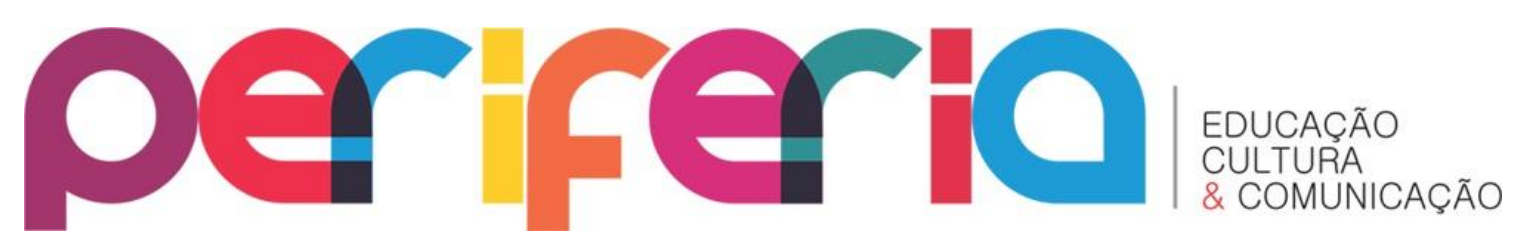

\section{INTRODUÇÃO}

O debate sobre o papel das indústrias culturais nas sociedades contemporâneas pode ser renovado com o advento das tecnologias de informação e comunicação, sendo possível observar mudanças na reprodução da cultura com o uso e a difusão dessas tecnologias. As indústrias culturais - televisão, jornais, rádios, impressos empregam meios informativos utilizados nas esferas pública e privada e atuam produzindo/distribuindo conteúdos para as massas. A comunicação de massa, segundo Camponez (2002), é entendida como um tipo de comunicação em que a mensagem é transmitida de um centro emissor para uma "pluralidade de indivíduos receptores" ( $p$. 76). E, por sua estrutura, pode se tornar uma forma unidirecional de transmissão de informações que tende a ser, hegemonicamente, autoritária e vertical.

Diferentemente dessa estrutura, as redes digitais permitem estabelecer processos bidirecionais, em que os receptores também podem se tornar agentes emissores, aumentando a possibilidade efetiva de ocorrência de fenômenos comunicativos de forma rizomática ${ }^{2}$. Elas se diferem dos meios utilizados pela indústria cultural, que na maioria das vezes mantém uma arquitetura vertical e centralizada. 0 território digital cria uma zona dentro de outros territórios, onde é possível acessar, produzir e distribuir informação de maneira autônoma, estabelecendo redes colaborativas e processos comunicativos mais complexos.

Observa-se que pode haver renovação do embate pela hegemonia na sociedade civil, e a mídia pode ser analisada como suporte ideológico dos sistemas hegemônicos de pensamento, mas também como lugares de produção de estratégias que objetivam reformular o processo social, atuando como instrumento de ação contra-hegemônica. Compreende-se que as redes digitais são os territórios onde as

\footnotetext{
${ }^{2}$ Rizoma é um conceito utilizado por Deleuze e Guattari (1995), nas ciências sociais, a partir de uma apropriação de um conceito da Botânica, área da Biologia que estuda as plantas. Nessa área, rizoma refere-se a um tipo de caule que algumas plantas verdes possuem que cresce horizontalmente. Esses autores apropriaram-se desse conceito para explicitar fenômenos sociais nos quais não se determina um começo ou fim; os fenômenos estão sempre no meio, imbuídos de outros fenômenos, em intermezzo, sem uma causa definida ou consequência preestabelecida.
} 


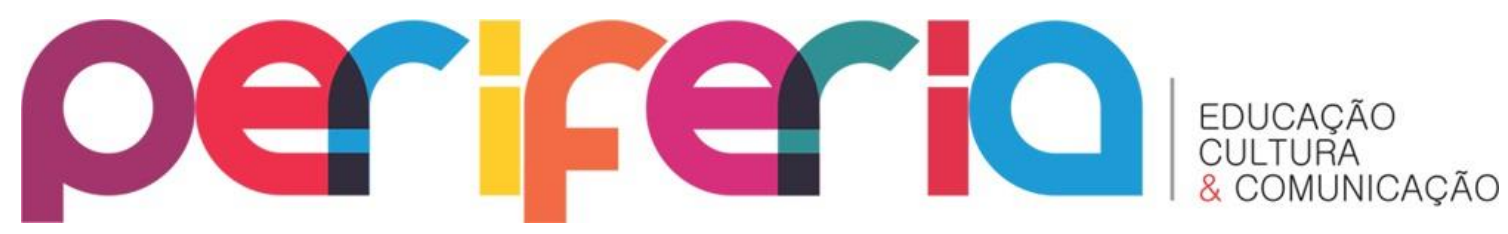

ideias contra-hegemônicas dos movimentos sociais encontram instrumento, divulgação e penetração na sociedade civil para exercer a sua resistência.

\section{A INDÚSTRIA CULTURAL NA CONTEMPORANEIDADE}

Nos tempos atuais, a família, a escola, o Estado, a religião e o trabalho não podem ser mais analisados e interpretados sem levar em conta as práticas midiáticas e as recepções/apropriações de seus conteúdos. As mídias exercem papel fundamental na sociedade contemporânea devido ao seu poder de penetração material e simbólico no cotidiano das pessoas, tornando-se plausível, e até mesmo necessário, pensar a cultura e as ações sociais relacionando-as às mídias.

A maioria dos conglomerados midiáticos globais está nas mãos de grandes empresas, que veiculam informações e conteúdos de acordo com seus interesses econômicos e parcerias ideológicas. Entre esses conglomerados estão estúdios, produtoras, distribuidoras e exibidoras de filmes, gravadoras de discos, editoras, emissoras de TVs abertas e pagas, emissoras de rádio, revistas, jornais, portais on-line, agências de publicidade e marketing, telefonia celular e agências de notícias (MORAES, 2004).

Os estudos dos meios de comunicação atrelados a questões econômicas, políticas e sociais tiveram inicialmente grande contribuição de dois pesquisadores, Adorno e Horkheimer (1985), que, a partir de uma abordagem interdisciplinar do marxismo, criaram o termo/conceito de indústria cultural. Adorno (1977) afirma que ele e Horkheimer empregaram o termo indústria cultural pela primeira vez no livro Dialética do Esclarecimento, publicado em 1947, após abandonarem a expressão "cultura de massa" que utilizavam em seus esboços. O abandono de tal expressão se justifica porque cultura de massa pode dar a entender que se está analisando a cultura produzida por uma massa, por um povo, quando, na verdade, os autores queriam denunciar a cultura imposta ao povo; assim, tem-se que indústria cultural é radicalmente definida como uma expressão distinta daquela. 


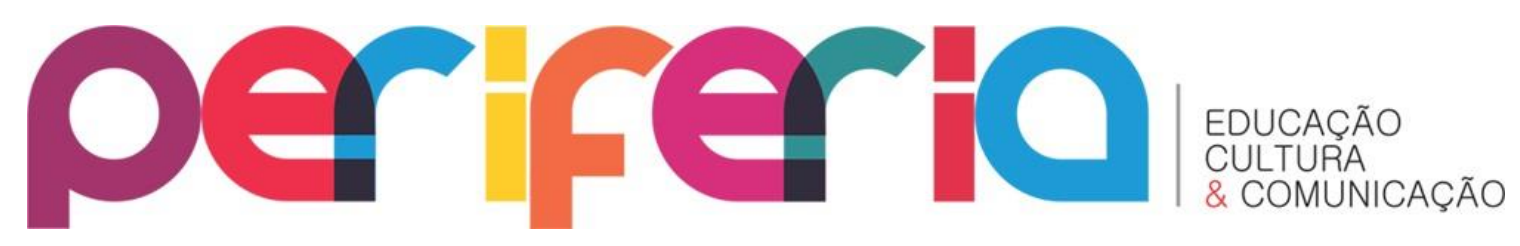

Em nossos esboços tratava-se do problema da cultura de massa. Abandonamos esta última expressão para substituí-la por "indústria cultural", a fim de excluir de antemão a interpretação que agrada aos advogados da coisa; estes pretendem, com efeito, que se trata de algo como uma cultura surgindo espontaneamente das próprias massas, em suma, da forma contemporânea da arte popular. Ora, dessa arte a indústria cultural se distingue radicalmente. Ao juntar elementos de há muito correntes, ela atribui-lhes uma nova qualidade. Em todos os seus ramos fazem-se, mais ou menos segundo um plano, produtos adaptados ao consumo das massas e que em grande medida determinam esse consumo (ADORNO, 1977, p. 287).

A ênfase dada por Adorno às diferenças entre os termos "cultura de massa" e "indústria cultural" é exposta de forma radical. Enquanto a cultura de massa se originaria do povo, de maneira espontânea, sem visar ao consumo deliberado e apresentando originalidade e identidade própria, a indústria cultural revelaria meios de comunicação preocupados em homogeneizar conteúdos a fim de gerar hábitos de consumo para os produtos que ela promove, percebendo o povo como receptor e consumidor passivo.

Dessa forma, a expressão indústria cultural estaria associada não somente aos meios de comunicação, mas também à produção industrial de bens e serviços culturais para as massas. E sua função principal consiste em oferecer o que é vendável, o que tem mercado para ser consumido e o consumidor como objeto de lucro. Com a amplitude da definição do conceito de indústria cultural cunhado por Adorno e Horkheimer (1985), pode-se afirmar que o mesmo é bastante contemporâneo e aplicável a análises de práticas sociais que envolvem os grandes conglomerados de comunicação.

Os meios de comunicação de massa configuram-se, ainda, como fortes colaboradores da formação do senso comum na esfera pública, dadas as suas estruturas verticais e centralizadas, sob o comando de poucos emissores e distribuindo conteúdos para uma grande massa de receptores. E como os grandes meios de comunicação estão nas mãos de empresários - e muitas vezes com parcerias com o 


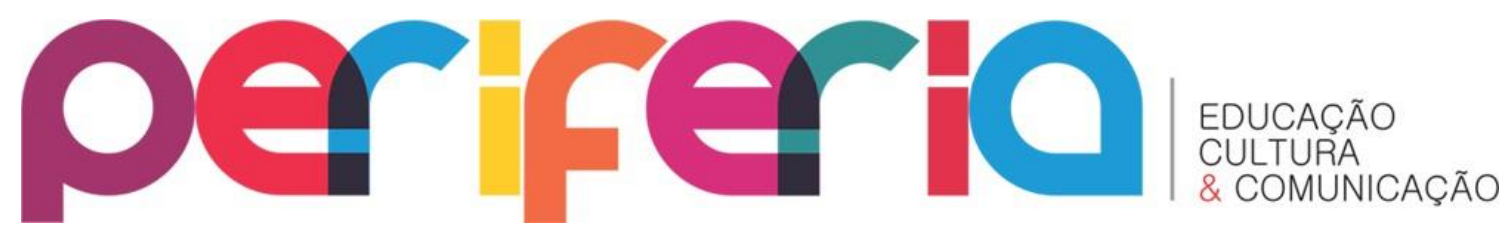

Estado -, podem ser observadas intenções/práticas de hegemonização de pensamentos e consenso junto ao público.

Warnier (2000), em uma análise do desenvolvimento da aplicabilidade do conceito de indústria cultural, forneceu um panorama de comparação deste com culturas ditas tradicionais, alheias às mídias. $\mathrm{O}$ autor aponta que foi preciso esperar que o conceito de indústria cultural passasse a ser utilizado, no final dos anos 1970, para que se pudesse vislumbrar questões interdisciplinares relativas às práticas dos meios de comunicação e suas relações com manifestações culturais já existentes, como a música, a fotografia e até mesmo a cultura oral. Warnier (2000) também aponta que as indústrias culturais, estruturalmente,

[...] necessitam de grandes meios financeiros; utilizam técnicas de reprodução em série; trabalham para o mercado (ou mercantilizam a cultura); são baseadas em uma organização do trabalho do tipo capitalista (transformam o criador em trabalhador e a cultura em produtos culturais) (p. 27-28).

Com base nessas características, torna-se viável fomentar reflexões complexas sobre as indústrias culturais em que é possível salientar que estas são, portanto, antes de mais nada, atividades industriais que produzem e comercializam discursos, sons, imagens, artes e qualquer outra capacidade ou hábito adquirido pelo homem como características da cultura. Diante disso, faz-se necessário elucubrar que os estudos feitos por Adorno e Horkheimer (1985) foram de total importância não só para sua época, mas para os dias de hoje. Adorno reelaborou o conceito de indústria cultural e não permitiu cair no ostracismo, renegando as formas tecnológicas da cultura, bem como os meios de divulgação de massa presentes à época.

Embora complexo, o conceito de indústria cultural é algo que faz parte do cotidiano, e a sociedade atual é irremediavelmente o lar da indústria cultural. Neste trabalho, o que se propõe é a compreensão e a contextualização da indústria cultural para que seja possível pensar em alternativas à comunicação hegemônica. 


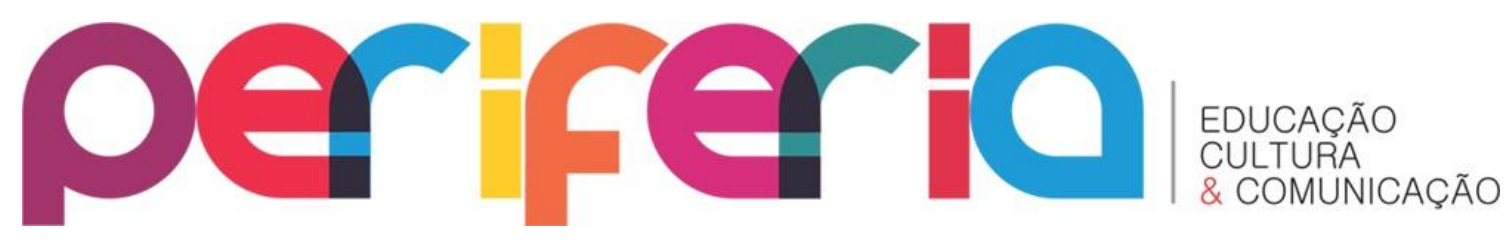

\section{HEGEMONIA E CONTRA-HEGEMONIA NAS MÍDIAS}

O conceito de hegemonia, proposto por Gramsci, é bastante relevante para análises dos sistemas político, econômico e social e oferece boa base para o estudo das práticas midiáticas imbricadas por tais sistemas. Para Gramsci (2002), a hegemonia corresponde à liderança cultural e ideológica de uma classe sobre as demais, pressupondo a capacidade de um bloco histórico (aliança de classes e frações de classes, duradoura e ampla) dirigir moral e culturalmente, de forma sustentada, toda a sociedade. Segundo Moraes (2009, p. 35), a hegemonia "tem a ver com disputas de sentido e entrechoques de visões de mundo, bem como com mediações de forças em determinado contexto histórico".

Contudo, um processo hegemônico não pode ser percebido como algo estanque e imposto para sempre; segundo Fairclough (2001), a

[...] hegemonia é o poder sobre a sociedade como um todo de uma das classes economicamente definidas como fundamentais em aliança com outras forças sociais, mas nunca atingido senão parcial e temporariamente, como um "equilíbrio instável" (p. 122).

Por ser uma categoria dinâmica, a hegemonia pressupõe negociações, compromissos e renúncias por parte do grupo dirigente que se pretende hegemônico. Para Gramsci (2002), a hegemonia não pode ser garantida sem desconsiderar demandas mínimas da classe dominada, sendo fundamental que a classe dirigente saiba ceder e saiba realizar sacrifícios no intuito de preservar esse instável equilíbrio de forças. Ainda segundo Gramsci (idem, p. 47), a conservação da hegemonia

[...] pressupõe indubitavelmente que sejam levados em conta os interesses e as tendências dos grupos sociais sobre os quais a hegemonia será exercida, que se forme um certo equilíbrio de ordem econômico-corporativa, isto é, que o grupo dirigente faça sacrifícios de ordem econômico-corporativa.

As indústrias culturais buscam, em suas práticas, hegemonizar valores e sentidos junto aos receptores; tais valores podem estar ligados às suas estratégias econômicas ou ideológicas, estabelecendo, assim, parcerias com diversos segmentos 


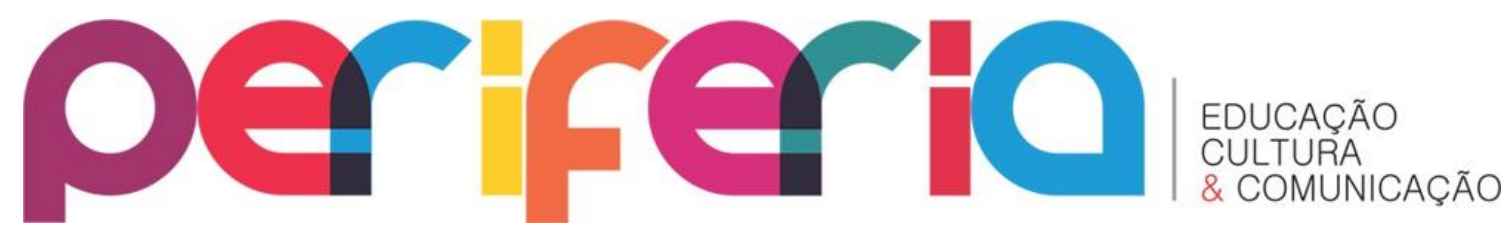

sociais, tanto privados como estatais. Os grandes conglomerados midiáticos se empenham em manter realidades que Ihes são benéficas e lucrativas; para isso, aprisionam e sincronizam seus espectadores e os deixam inertes a seus controles, tornando-os marionetes dos seus espetáculos. Hegemônicos na defesa de seus interesses, os conglomerados manipulam fatos sociais e os transformam, muitas vezes, em uma realidade falsa, mas crível, para os espectadores.

Como dito, a hegemonia não existe passivamente como forma de dominação; ela se renova continuamente, recria-se, defende-se, modifica-se e sofre resistência continuada e desafiante. Tal resistência foi denominada, por Gramsci (1995), "contrahegemonia". A função primordial de uma ação contra-hegemônica é fazer com que a sociedade reflita, pense e seja dona de suas próprias escolhas de acordo com a sua consciência crítica. Para tanto, a convergência ideológica, política e cultural, na sua totalidade é condição determinante para consolidar a contra-hegemonia.

Segundo Gramsci (1995), uma força contra-hegemônica só pode ser reconhecida como tal na medida em que consegue ultrapassar a espontaneidade do movimento, em que contribui com a capacidade de modificar e alterar uma dada estrutura social. Por exemplo, para quebrar as amarras hegemônicas da mídia tradicional, que pensa somente em seus próprios interesses e no consumo, é preciso que haja mais mídias contra-hegemônicas. Estas, por sua vez, têm que estar dispostas a alterar o cenário e buscar saídas democráticas e de participação popular a partir de iniciativas como rádios e televisões comunitárias, imprensas alternativas e o acesso à livre circulação das informações - na internet, por exemplo. Para Góes (2007, p. 13),

[...] dentro de uma leitura gramsciana, o ciberespaço na atualidade seria o ambiente onde as ideias contra-hegemônicas dos movimentos sociais encontram instrumento, divulgação e penetração na sociedade civil para exercer a sua luta. A sua importância estaria na ruptura da unidirecionalidade da comunicação; na pluralidade e diversidade de informações e pontos de vistas que a web oferece; nas novas possibilidades de o público ter de verificar, direta ou indiretamente, a veracidade da informação que está recebendo, e de tomar sua própria decisão. 


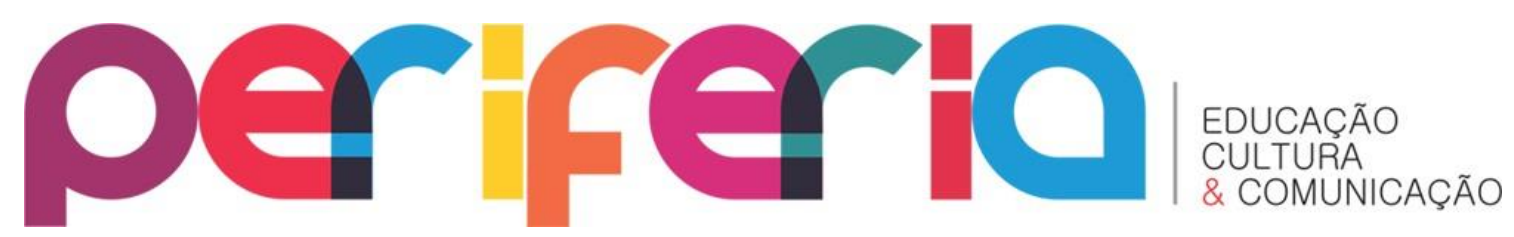

A internet, portanto, pode permitir processos de comunicação alternativos aos grandes conglomerados, em que receptores podem ser emissores e receptores ao mesmo tempo, criando suas próprias plataformas comunicacionais. Isso não quer dizer que os conglomerados não estejam na internet; pelo contrário, suas estratégias caminham cada vez mais para a web, porém os espaços oferecidos pela internet são infinitos, permitindo mobilizações alternativas que antes eram raras nos meios de comunicação tradicionais.

É válido ressaltar que Gramsci (2001) refletiu sobre o principal meio de comunicação de sua época - a imprensa. "A arte da imprensa revolucionou todo o mundo cultural, dando à memória um subsídio de valor inestimável e permitindo uma extensão inaudita da atividade educacional" (p. 67). Ele não teve tempo de vida para aquilatar a evolução dos modernos meios de comunicação no século XX; entretanto, ainda no início da década de 1930, observava que a imprensa escrita já sofria a concorrência de outros veículos, como os da comunicação falada. Nos Cadernos do cárcere, há a seguinte e expressiva observação sobre mutações que começavam a ocorrer na mídia de então graças ao avanço técnico e às tecnologias que despontavam:

Também hoje a comunicação falada é um meio de difusão ideológica que tem uma rapidez, uma área de ação e uma simultaneidade emotiva enormemente mais amplas do que a comunicação escrita (o teatro, o cinema e o rádio, com a difusão de alto-falantes nas praças, superam todas as formas de comunicação escrita, desde o livro até a revista, o jornal, o jornal-mural) (GRAMSCl, 2001, p. 67).

Gramsci (2001) também apontou que os meios de comunicação estavam sendo utilizados como estratégicas hegemônicas do Estado, muitas vezes em parceria com setores privados da sociedade com interesses ideológicos comuns aos seus. Nesse sentido, também apontou usos contra-hegemônicos dos meios de comunicação, como os jornais e manifestações da comunicação falada, principalmente a partir do uso de alto-falantes, produzidos e liderados pela classe trabalhadora.

Diante dos apontamentos de Gramsci e das apropriações contemporâneas de seus conceitos por Góes (2007), pode-se afirmar que o papel principal da mídia contra- 


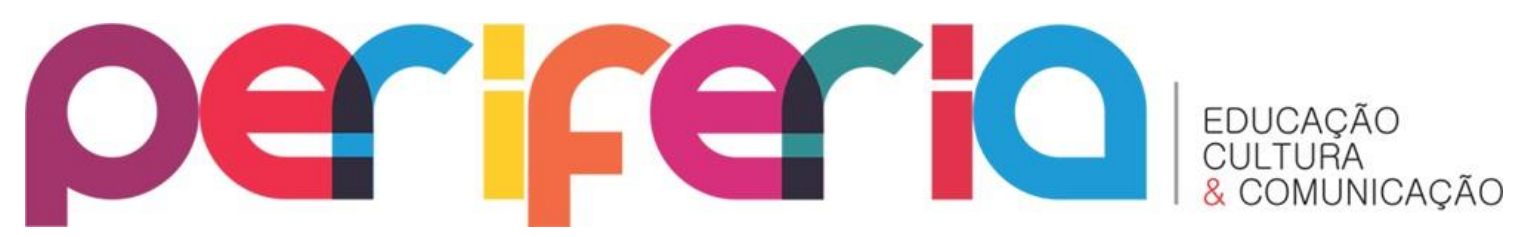

hegemônica deveria ser lutar contra o poder e o controle social hegemônico, como, por exemplo, a partir de iniciativas que estimulem a cobrança das políticas públicas sociais e que motivem o cidadão a se tornar um sujeito de direito e participante ativo da comunicação, no intuito de transformar realidades. O cenário contra-hegemônico contemporâneo, a partir da internet, por exemplo, poderá se transformar em um espaço de debates e de apoio ao movimento de ideias que estimulem a informação e a reflexão sobre os mecanismos e instrumentos da dominação.

\section{SISTEMA ARBORESCENTE E A RAIZ FASCICULADA}

Com os avanços tecnológicos do último século, podem-se observar significativas modificações nas formas de interação humana, principalmente por meio da proliferação das mídias digitais. Estas passaram a alterar exponencialmente a comunicação mundial por intermédio não mais exclusivo dos veículos de comunicação de massa, como impressos, rádios e televisões, mas, agora, pautados pela crescente disponibilidade de telefonia móvel, internet banda larga, satélites e toda a tecnologia digital de grande velocidade.

Nesse viés de análise tecnológica, Marshall McLuhan (1994) atribuía à mídia um papel ativo nos processos de transformação de toda estrutura do social, em que "as sociedades sempre foram influenciadas mais pela natureza dos media, através dos quais os homens comunicam, do que pelo conteúdo da comunicação" (p. 74). A partir dessa perspectiva, nota-se a importância estrutural da introdução de uma nova tecnologia da comunicação - que, desde o advento da escrita e da impressão no século XV, com a invenção de Gutenberg, acabou não somente alterando a forma de perceber, armazenar e comunicar, mas também incidiu sobre as diversas formas de organização da sociedade e do mundo. A cada nova tecnologia comunicacional, alterase não apenas a forma de comunicar - isto é, a quantidade de público atingido pela informação, reduzindo-se o tempo e os custos necessários à difusão -, mas, ao mesmo tempo, a organização da sociedade inteira, que passou por transformações qualitativas. 


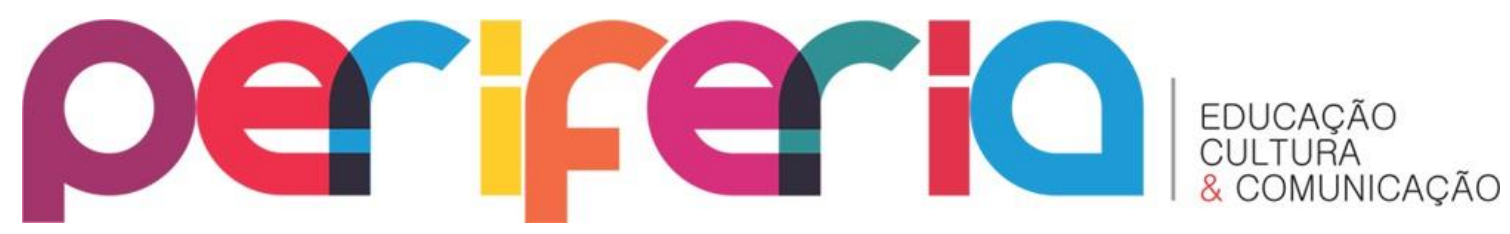

$\mathrm{Na}$ atualidade, o crescimento das redes mundiais de comunicação está sendo incorporado ao cotidiano das pessoas e passando a mediar interações sociais.

De fato, as novas tecnologias da comunicação permitiram esse maior e mais acessível fluxo de informação, ainda com menor censura, mas cabe ponderar. Especialmente nas duas últimas décadas, com o crescimento da internet e das telecomunicações, não só as expectativas em relação à democratização cresceram, como a tensão entre o micro e o macro (entre o público e o privado) tornou-se cada vez mais presente na sociedade, por meio da comunicação em rede sem fronteiras, que leva espaços individuais ao chamado espaço-mundo, com diferentes produtores de informação e conteúdo, sendo cada indivíduo um emissor em potencial (AGNEZ, 2012, p. 38).

É importante perceber que a comunicação, nessa nova conjuntura, não pode mais ser pautada apenas no paradigma clássico do emissor e receptor de mensagens; as novas tecnologias passam a ter novo papel social. André Parente (2004) aponta que a contemporaneidade é o momento em que as tecnologias de informação e da comunicação passam a ter papel crucial na nova ordem mundial e que as redes são, a um só tempo, uma espécie de paradigma e de personagem principal das mudanças em curso. O funcionamento das redes se difere das práticas da indústria cultural porque não possuem centros ou organização centralizadora, estatal ou privados. Os agrupamentos ou conexões de indivíduos se dão em diversas direções diferentes e sem nenhum critério além das intenções dos indivíduos. É como aponta André Lemos (2008, p. 68): "a circulação de informações não obedece à hierarquia da árvore (umtodos) e sim à multiplicidade do rizoma (todos-todos)".

Nessa linha de raciocínio, Lévy (1999) conceitua o ciberespaço como o novo meio de comunicação que surge da interconexão mundial dos computadores - a rede - não só em relação à infraestrutura material, "mas o oceano de informações que a comunicação digital abriga, assim como os humanos que navegam, habitam e se alimentam desse universo" (p. 17); ele destaca que a cibercultura seria, então, a cultura dotada de técnicas, valores, pensamentos e atitudes das pessoas que se articulam nesse novo espaço. 


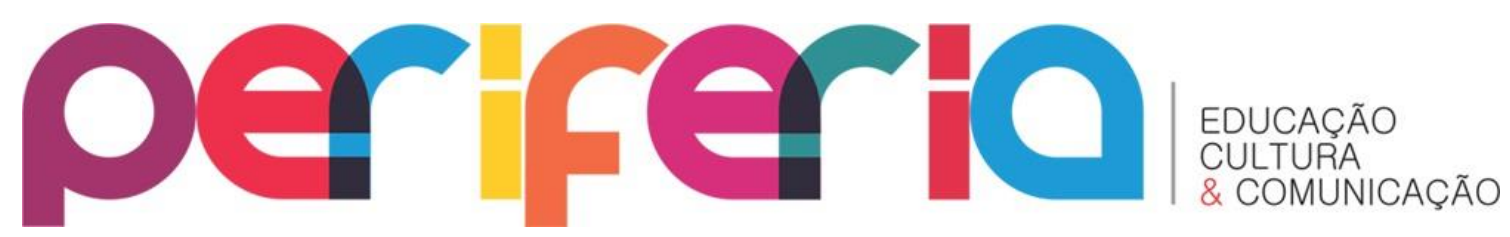

Para Lemos (2003), a cibercultura é também a forma sociocultural que emerge da relação simbiótica entre a sociedade, a cultura e as novas tecnologias de base microeletrônica que surgiram com a convergência das telecomunicações com a informática na década de 1970. Lemos (2006) propõe três categorias/explicitações que regem a cibercultura. A primeira delas refere-se à liberação do polo da emissão, possibilitando, assim, a multiplicação de agentes emissores e a quebra de monopólios de elaboração da informação. A segunda diz respeito ao princípio da conexão generalizada, que é a participação e colaboração de pessoas nos conteúdos. E a terceira está relacionada à reconfiguração da paisagem comunicacional, que se refere à ideia de modificação das estruturas sociais, das instituições e das práticas comunicacionais. É válido apontar que a nova paisagem comunicacional não aniquila o poder e a força dos meios de massa da indústria cultural; eles coexistem, porém a nova paisagem pode permitir a reconfiguração das formas de produção e da circulação de informação.

Como se percebe, quando se pensa na comunicação em redes qualquer pessoa pode produzir textos, mensagens e informações e publicá-los na internet, tornando-os acessíveis a todos aqueles que se conectam à rede. Lévy (2003, p. 209) afirma que, "como dizia um consultor americano a um dirigente da International Business Machines (IBM), uma criança encontra-se aí em situação de igualdade com uma multinacional", pois o rizoma pressupõe a inexistência de hierarquias ou centros.

Pierre Lévy, ao justificar a necessidade de pensar sobre a cibercultura, aponta dois fatos:

[...] em primeiro lugar, o crescimento do ciberespaço resulta de um movimento internacional de jovens ávidos para experimentar, coletivamente, formas de comunicação diferentes daquelas que as mídias clássicas nos propõem. Em segundo lugar, que estamos vivendo a abertura de um novo espaço de comunicação, e cabe apenas a nós explorar as potencialidades mais positivas deste espaço nos planos econômico, político, cultural e humano (LÉVY, 2010, p. $11)$. 


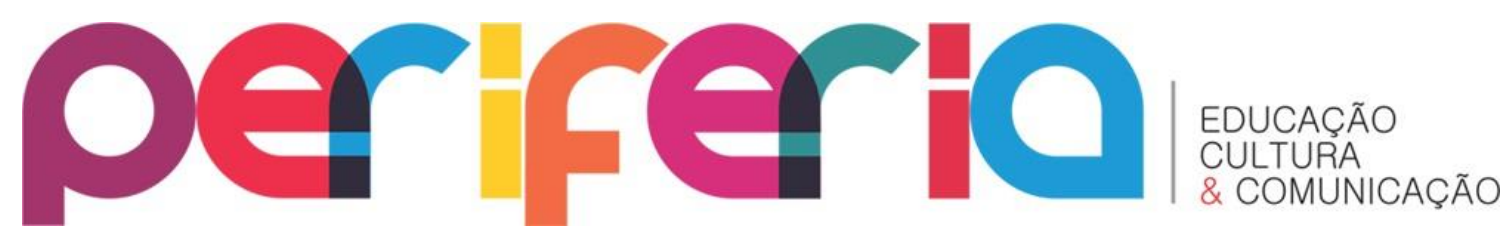

Essa afirmação contribui para evidenciar a relação entre tecnologias e comunicação. É interessante perceber que os dois fatos envolvem o reconhecimento da relação entre cibercultura e comunicação. Nas palavras do autor, o ciberespaço proporciona formas de comunicação diferentes e novo espaço de comunicação. Lévy fala em experimentar essas diferentes formas de comunicação e explorar este espaço comunicativo e comunitário. Lévy (2003) também considera que isso só é possível porque a web articula uma multiplicidade de pontos de vista. Para o autor, a ideia de cibercultura descreve um novo tempo e um novo mundo para as mídias, em que se impõe a necessidade de estar permanentemente conectado. Percebe-se então que o crescimento da internet e as mudanças de forma de participação nela contribuíram para a compreensão de uma chamada web 2.0, na qual usuários não apenas consomem informações como também as produzem e divulgam de modo colaborativo (VALENTE; MATTAR, 2007; VILAÇA, 2011), de formas variadas. Como discutido em Vilaça (2011), a web 2.0 não se refere à velocidade ou tecnologia de acesso, mas às práticas sociais desenvolvidas nela. $\mathrm{Na}$ web 2.0, passamos de uma internet predominantemente receptiva - da leitura e audição e de consumo de informações para uma internet ativa, da escrita e da fala e produtiva de informações. A internet ajudou a dar voz, visão e visibilidade a diferentes questões sociais.

Compreende-se então, que as redes digitais instauram uma forma comunicativa feita de fluxos e de troca de informações de todos para todos, modificando as práticas de comunicação que eram apenas verticais. Sergio Amadeu (2009) destaca a importância da observação das estruturas das redes; primeiro porque elas têm

[...] um desenho e uma geometria diferenciados. Segundo, porque as redes são flexíveis e é provável que o grau de flexibilidade interfira na comunicação; terceiro, porque as características de uma rede digital, por exemplo, a organização, as regras de conectividade, o desenho podem influenciar a formatação dos conteúdos comunicados, a velocidade de transferência das informações e até mesmo os próprios conteúdos (AMADEU, 2009, $s / n)$. 


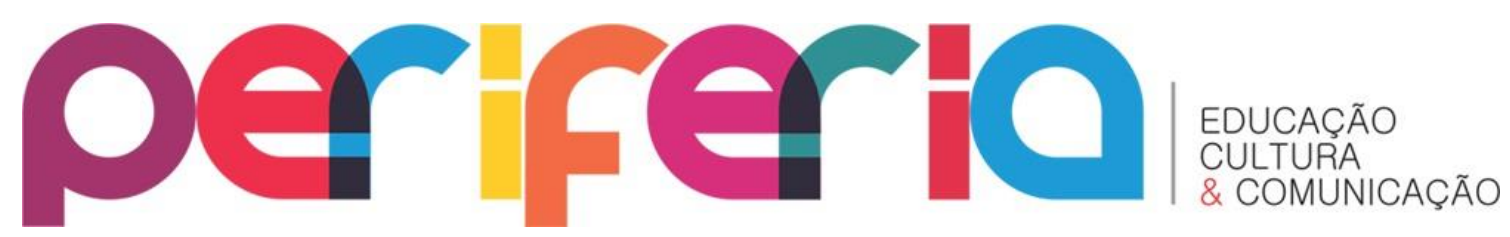

Como exemplo, têm-se aqueles que constroem páginas, perfis na rede e expõem seus pontos de vista tanto sobre determinado assunto quanto sobre sua própria vida. Quando alguém escreve algo em um blog, por exemplo, mostra ali sua opinião, seu ponto de vista sobre determinado assunto. Quando alguém cria um perfil em uma rede social, posta suas melhores fotos, seus melhores links, suas melhores frases, aquilo que pensa de si e da sociedade na qual está inserido. Lévy (2003, p. 214) afirma que "qualquer um terá sua página, seu mapa, seu site, seu ou seus pontos de vista. Cada um se tornará autor, proprietário de uma parcela do ciberespaço". Entretanto, essas páginas, sites e mapas dialogam, interconectam-se e confluem por canais móveis e labirínticos, o que Lévy $(1999$, p. 160) também denomina rizoma.

Na web, tudo se encontra no mesmo plano. E no entanto tudo é diferenciado. Não há hierarquia absoluta, mas cada site é um agente de seleção, de bifurcação ou de hierarquização parcial. Longe de ser uma massa amorfa, a web articula uma multiplicidade aberta de pontos de vista, mas essa articulação é feita transversalmente, em rizoma, sem o ponto de vista de Deus, sem uma unificação sobrejacente.

Verifica-se, então, que na comunicação rizomática há uma dimensão descentralizada e cada vez menos hierarquizada. No contexto da internet não interessa criar modelos, propor caminhos, impor soluções; não se trata de buscar a complexidade de uma suposta unidade perdida, mas viabilizar conexões horizontais descentralizadas. Já os meios de comunicação de massa da indústria cultural correspondem a um modelo fundado na visão arborescente, que, diferentemente do modelo rizomático, possui formato hierárquico, elege mecanismos de delimitação de fronteiras e mapeia os canais de circulação de pessoas e coisas em um território estratificado na forma de um espaço estriado ${ }^{3}$. A árvore é como uma foto, um rádio

\footnotetext{
${ }^{3}$ Deleuze e Guattari $(1995$, p. 487) propõem uma distinção entre dois tipos de espaço: o liso e o estriado. No espaço liso do controle, as instituições se volatizam, perdendo suas fronteiras e mantendo entre si uma relação de modulação num continuum regulador. Já o espaço estriado é abordado, segundo Deleuze, como aquele demarcado por fronteiras e hierarquias, no interior do qual as instituições exercem poder. Espaço delimitado, fixo, distinto, ao contrário do espaço liso, que funciona a partir de redes flexíveis moduláveis. Deleuze e Guattari deixam claro que esses dois espaços podem
} 


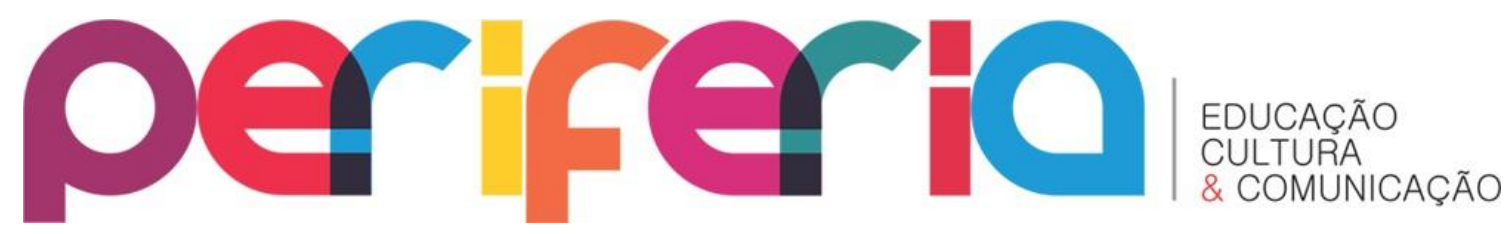

que começaria por eleger ou isolar o que ele tem a intenção de reproduzir com a ajuda de meios artificiais. Escrever, pensar, coletar, colecionar, classificar e registrar; todas essas atividades ou habilidades podem ser agenciadas a partir do modelo árvore e, então, se pode perceber que no sistema arborescente existe uma segmentação das áreas de conhecimento em que estas só se comunicam a partir do tronco central, como nas mídias de massa (DELEUZE: GUATTARI, 1995).

O rizoma não é modelo, mas processo imanente descentralizado, sem chefe ou estrutura administrativa superior, em que os canais de comunicação não são preexistentes e nos quais todos os elementos são intercambiáveis.

É preciso fazer o múltiplo, não acrescentando sempre uma dimensão superior, mas, ao contrário, da maneira simples, com força de sobriedade, no nível das dimensões de que se dispõe, sempre n-1 (é somente assim que o uno faz parte do múltiplo, estando sempre subtraído dele). Subtrair o único da multiplicidade a ser construída; escrever a $\mathrm{n}-1$, tal sistema poderia ser chamado de rizoma (DELEUZE; GUATTARI, 1995, p. 14-15).

Deleuze e Guattari (1995) propuseram alguns princípios relacionados à constituição/funcionamento do rizoma que permitem vislumbrar ainda mais a complexidade desse conceito. Inicialmente, o primeiro e segundo princípios - de conexão e heterogeneidade - significam que qualquer ponto de um rizoma pode ser conectado com qualquer outro: "um rizoma não cessaria de conectar cadeias semióticas, organizações de poder, ocorrências que remetem às artes, às ciências, às lutas sociais. Uma boa cadeia semiótica é como um tubérculo que aglomera atos muito diversos" (p. 16). Ou seja, não há dicotomizações nem processos hierárquicos, como em uma árvore, e a heterogeneidade se desenvolve no bojo das conexões, visto que, ao se conectar com qualquer ponto, as características produzidas acabam por ser diversas.

interpenetrar-se e transformar-se um no outro, o que implica dizer que esses espaços convivem lado a lado. Na verdade, pode-se também dizer que a comunicação em redes não elimina a comunicação de massa da indústria cultural e que ambas convivem na contemporaneidade. 


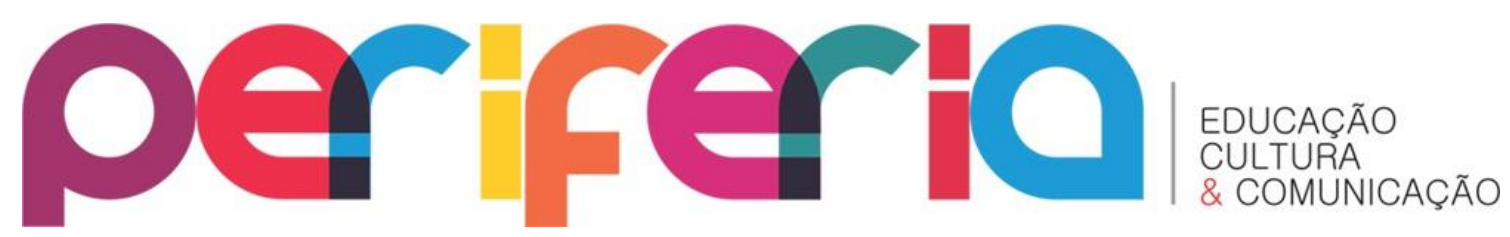

O terceiro princípio - de multiplicidade - afirma que o rizoma não mantém relação com o uno, pois em um rizoma encontram-se somente linhas ${ }^{4}$ e não pontos ou posições, como numa estrutura, numa árvore. Assim, na instância da multiplicidade, não faz sentido falar de sujeito ou de objeto, já que se trata aqui de grandezas e determinações que se expandem de acordo com seus agenciamentos. "Um agenciamento é precisamente esse crescimento das dimensões numa multiplicidade que muda necessariamente de natureza na medida em que ela aumenta suas conexões" (DELEUZE; GUATTARI, 1995, p. 17). O quarto princípio - de ruptura assignificante - considera que um rizoma pode ser rompido e quebrado em um lugar qualquer, mas também pode ser retomado a partir de suas próprias linhas ou agrupando outras. Cada vez que há uma ruptura no rizoma, as linhas segmentares explodem em uma linha de fuga, mas essas linhas de fuga são parte do rizoma, ou seja, as linhas não param de remeter umas às outras. Nesse sentido, o quinto e o sexto princípios - de cartografia e de decalcomania - podem ser interpretados, nesse contexto, como o refazer do já feito.

O mapa rizomático é feito de conexões, é aberto, "desmontável, invertível, susceptível de receber modificações constantes" (DELEUZE; GUATTARI, 1995, p. 32). Cartografar é acompanhar os acontecimentos, perceber as constantes mudanças do mapa que está sempre se reconfigurando em seus movimentos, ou seja, mapas que se fazem e desfazem instantaneamente; por isso, um rizoma não pode ser justificado por nenhum modelo estrutural. Isso significa que os rizomas não podem ser modelados, pois são sempre esboços incompletos e abertos.

De acordo com Pinheiro e Silva (2008), o rizoma, utilizado como metáfora para as redes, constitui-se de nós interligados que conectam qualquer ponto,

\footnotetext{
${ }^{4}$ Deleuze e Guattari (1995) apontam três tipos de linhas que compõem nossas relações: as de segmentaridade dura, características dos grandes conjuntos molares ou estratos, como as classes sociais e os gêneros; as de segmentaridade maleável, caracterizadas por relações moleculares de desestratificações relativas, com velocidades acima ou abaixo dos limites da percepção, e que, ao contrário dos grandes movimentos e cortes que definem os estratos, compõem-se de elementos rizomáticos sempre em devir, fluxos sempre em movimento que retiram o homem da rigidez dos estratos; e as linhas de fuga, que se caracterizam por uma ruptura com os estratos ou sua desestratificação absoluta.
} 


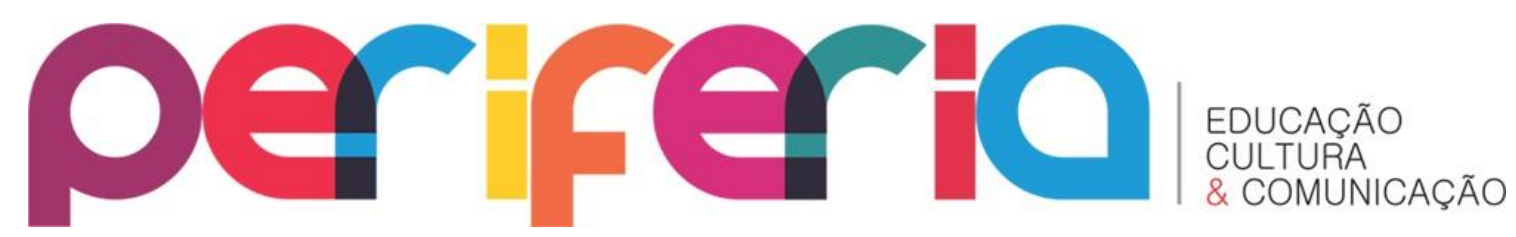

independentemente da sua natureza. Além disso, não é feito de unidades e sim de dimensões, não tem começo nem fim, mas possui um meio pelo qual cresce e se estende. Para os autores, o conceito de rizoma reforça o sentido de horizontalidade das formas de comunicação e organização sociais, opondo-se ao sentido hierárquico a que seu crescimento vertical nos remete.

Pensando a comunicação como rizoma e não como árvore, pode-se observar que as informações tendem a soar como linhas que se misturam, como teias de possibilidades, multiplicidade de nós, de conexões e de interconexões. Se a árvore não estimula e não permite o diálogo, o rizoma, ao contrário, estimula os encontros e as conjunções. E se a imagem da árvore implica um sistema fechado e unitário, a imagem do rizoma, por sua vez, implica um sistema aberto e múltiplo, pois não é composta de um percurso apenas, mas inúmeros percursos, com pontos de partida e pontos de chegada distintos - o que não inviabiliza encontros; pelo contrário, possibilita-os, promove-os e os estimula.

\section{CONSIDERAÇÕES FINAIS}

Neste trabalho, observou-se que o debate sobre o papel da indústria cultural e da mídia nas sociedades contemporâneas é renovado com o advento das redes digitais de comunicação, em que o modelo de redes promove uma série de mudanças e disputas. As novas mídias, com funcionamento em rede, caminham pelos espaços lisos e promovem a desterritorialização dos espaços estriados das mídias de massa, resistindo à sua captura. Deleuze e Guattari (1995) descrevem a dinâmica do social como um plano de segmentaridades rígidas e segmentaridades flexíveis, sendo o Estado um organizador centralizante de políticas chamadas molares, ou seja, que formatam e homogeneízam. Os autores também descrevem a existência de redes complexas, de diferentes modos de organização, que produzem conflitos e linhas de fuga, micropolíticas, que se conectam reticularmente, pois "do ponto de vista da micropolítica, uma sociedade se define por suas linhas de fuga, que são moleculares" (p. 94). 


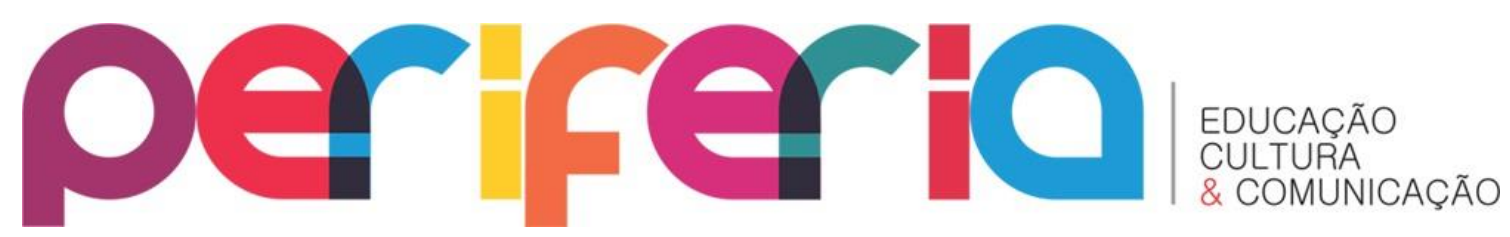

Pode-se observar que, nas redes, todos estão em constante movimento; seus fluxos são micro-moleculares e possuem um plano de segmentaridades flexíveis, pois a rede é nômade por excelência. Já os meios de comunicação de massa da indústria cultural são sedentários e territorializados e seus fluxos são macro-molares. A relação dos meios massivos com a mobilidade é sempre constrangedora, pois eles possuem um plano de segmentaridades rígidas, em que os sujeitos não têm voz e são apenas consumidores. Por sua vez, nas mídias de função pós-massiva ${ }^{5}$, móveis e em rede, há possibilidades de consumo, mas também de produção e distribuição de informação por todos os participantes.

O modelo reticular das novas mídias e o modelo arbóreo da indústria cultural existem concomitantemente, pois, como já abordado, a indústria cultural está englobando a internet em suas atividades. Percebem-se a complementaridade entre diferentes meios de comunicação, a proliferação da oferta midiática e a ampliação dos usos possíveis feitos para cada um deles ou, cada vez de forma mais incisiva, entre eles e de forma combinada. Assim, pode-se dizer que o modelo de comunicação massiva se mantém e pode ser identificado em lógicas presentes na própria rede, mas é impactado por um modelo de comunicação que se baseia, entre outros aspectos, na relação entre as mídias, em um espaço de participação maior do público na produção da informação e de autonomia no processo comunicativo.

As novas tecnologias de comunicação e informação poderão ser vetores de agregação social, de vínculo comunicacional e de recombinações de informações das mais diversas sobre formatos variados, evidenciando muito bem o movimento de recombinação cultural em um território eletrônico (LEMOS, 2003). A conexão em rede instaura uma estrutura midiática ímpar na história da humanidade, na qual pela primeira vez qualquer indivíduo pode produzir e publicar informação em tempo real sob diversos formatos e modulações, adicionar e colaborar em rede com outros, inclusive reconfigurando a indústria cultural. Trata-se de crescente troca e processo de

\footnotetext{
${ }^{5}$ As chamadas mídias pós-massivas, "caracterizam-se por abertura do fluxo informacional, pela liberação da emissão e pela transversalidade e personalização do consumo da informação" (LEMOS; LÉVY, 2010, p. 48)
} 


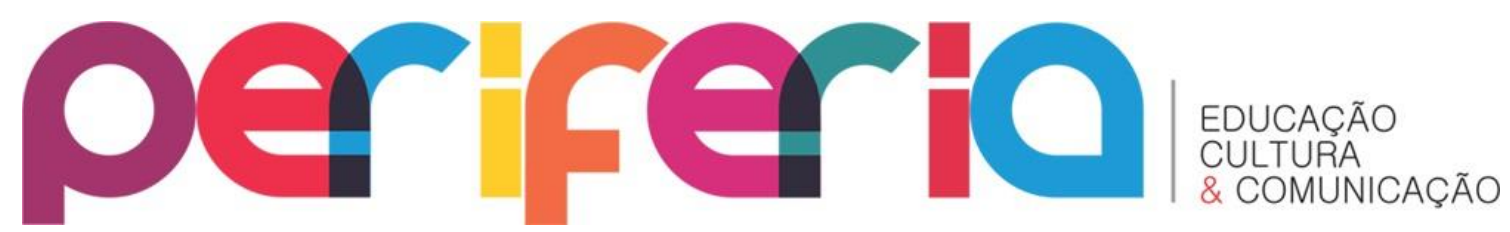

compartilhamento de diversos elementos da cultura a partir das possibilidades abertas pelas tecnologias eletrônico-digitais e pelas redes telemáticas contemporâneas. Podese dizer que, atualmente, estamos imersos em uma paisagem audiovisual dupla, na qual dois sistemas comunicacionais amplos, complementares e às vezes antagônicos coexistem, oferecendo maior pluralidade infocomunicacional: o modelo arbóreo da indústria cultural, caracterizado pelas mídias tradicionais, e o modelo rizomático, caracterizado pelas mídias digitais, redes telemáticas e processos recombinatórios de conteúdo informacionais emergentes.

O que conta é que a árvore-raiz e o rizoma-canal não se opõem como dois modelos: um [a árvore] age como modelo e como decalque transcendente, mesmo que engendre suas próprias fugas; o outro [o rizoma] age como processo imanente que reverte o modelo e esboça um mapa, mesmo que constitua suas próprias hierarquias, e inclusive ele suscite um canal despótico (DELEUZE; GUATTARI, 1995, p. 31).

Enfim, este trabalho procurou tecer considerações sobre a indústria cultural e as novas mídias, no intuito de vislumbrar que tais conceitos representam estruturas que existem concomitantemente na contemporaneidade, cada uma com um modo de funcionamento diferenciado. O primeiro, voltado ao lucro e à hegemonização das massas; o segundo, permeado e produzido por conglomerados comunicacionais, mas também por todos. Encerra-se este trabalho incitando práticas horizontais nas novas mídias que produzam novos conteúdos e que questionem a indústria cultural, que, por sua vez, sorrateiramente, em suas estratégias, já está tentando dominar as novas mídias, hegemonizando, ali também, seus conteúdos e ideologias.

\section{REFERÊNCIAS}

ADORNO, Theodor. e HORKHEIMER, Max. A Indústria cultural: o esclarecimento como mistificação das massas. In: Dialética do esclarecimento - fragmentos filosóficos. Tradução: Guido Antônio de Almeida. Rio: Zahar, 1985, pág. 99-138.

ADORNO, Theodor. A indústria cultural. In: COHN, Gabriel. (Org.). Comunicação e indústria cultural: leituras de análise dos meios de comunicação na sociedade contemporânea e das manifestações da opinião pública, propaganda e cultura de massa nessa sociedade. 5. ed. São Paulo: Ed. Nacional, 1977. pág. 287 


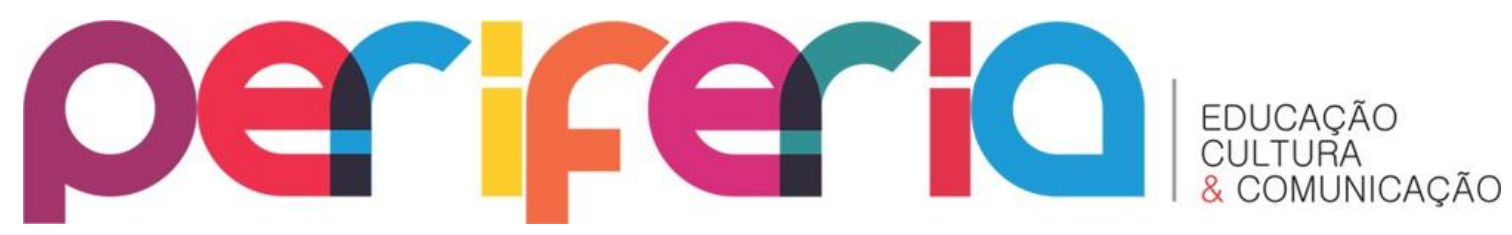

AGNEZ, Luciane Fassarella. A convergência digital na produção da notícia. Natal: UFRN, 2012.

AMADEU, Sérgio. Arquiteturas em disputa: ativistas P2P e a indústria da intermediação. Revista de Economia Política de las tecnologias da información y comunicación, vol. 11. Aracaju, Eptic: 2009.

CAMPONEZ, Carlos. Jornalismo de proximidade. Coimbra: Minerva, 2002.

CUNHA, Paulo (orgs.). Olhares sobre a cibercultura. Porto Alegre: Sulina, 2003.

DELEUZE, Gilles; GUATTARI, Félix. Mil platôs: capitalismo e esquizofrenia, v. 1. São Paulo: Ed. 34, 1995.

Mil platôs: capitalismo e esquizofrenia, v. 5. São Paulo: Ed. 34, 1995.

FAIRCLOUGH, Norman. Discurso e mudança social. Brasília: Editora UnB, 2001.

GRAMSCl, Antonio. Os intelectuais e a organização da cultura. Rio de Janeiro: Civilização Brasileira, 1995.

Cadernos do cárcere - temas de cultura: Ação Católica; americanismo; fordismo. Rio de Janeiro: Civilização Brasileira, 2001.

Cadernos do cárcere - Literatura; Folclore; Gramática; Apêndices: variantes e índices. Rio de Janeiro: Civilização Brasileira, 2002.

GÓES, Laércio. Contra-hegemonia e internet: Gramsci e a mídia alternativa dos movimentos sociais. IX Congresso de Ciências da Comunicação na Região Nordeste: Mercado, Região e Comunicação na Sociedade Digital. Salvador, 2007.

LEMOS, André. Cibercultura: Alguns pontos para entender a nossa época. 2006

- Ciber-cultura - remix. In: ARAUJO, Denize Correa (org.). Imagem (IR)

Realidade: comunicação e cibermidia. Porto Alegre: Sulina, 2006. pag. 52-65

LÉVY, Pierre. Cibercultura. São Paulo: Editora 34, 1999.

Cibercultura, tecnologia e vida social na cultura contemporânea. Porto Alegre:

Sulina, 2008.

LEMOS, André; LÉVY, Pierre. O futuro da internet: em direção a uma ciberdemocracia planetária. São Paulo: Paulus, 2010.

A revolução contemporânea em matéria de comunicação. In: MARTINS, Fernando (org.). Para navegar no século XXI: tecnologias do imaginário e cibercultura. 3a ed. Porto Alegre: Sulina/Ed. PUCRS, 2003. pág. 214

McLUHAN, Marshall. Os meios de comunicação como extensões do homem. São Paulo: Cultrix, 1994.

MORAES, Dênis de. A lógica da mídia no sistema de poder mundial. Revista de Economía Política de las Tecnologías de la Información y Comunicación, Aracaju, Eptic, v. 6, p. 16-36, maio/ago. 2004.

- A batalha da mídia: governos progressistas e políticas de comunicação na América Latina e outros ensaios. Rio de Janeiro: Pão e Rosas, 2009.

PARENTE, André. Tramas da rede: novas dimensões filosóficas, estéticas e políticas da comunicação. Porto Alegre: Sulina, 2004.

PINHEIRO, Liliane Vieira; SILVA, Edna Lúcia da. As redes cognitivas na Ciência da Informação brasileira: um estudo nos artigos científicos publicados nos periódicos da área. Ciência da Informação, Brasília, IBICT, v. 37, 2008. 


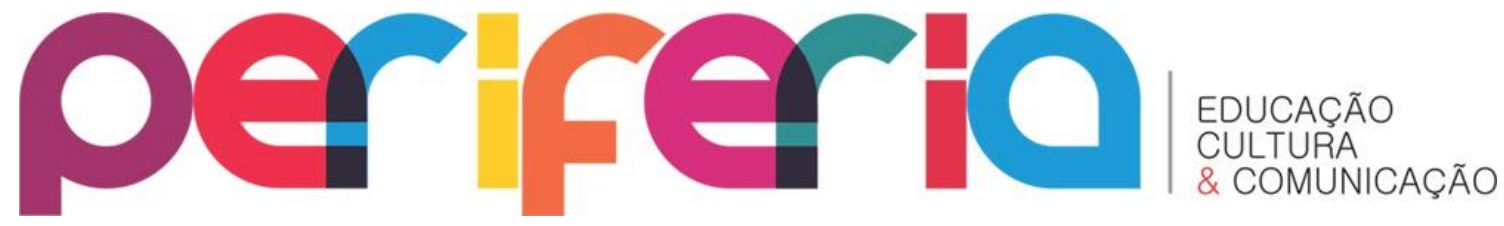

VALENTE, C.; MATTAR, J. Second life e web 2.0 na educação: o potencial revolucionário das novas tecnologias. São Paulo: Novatec, 2007.

VILAÇA, M. L. C. Web 2.0 e materiais didáticos de línguas: reflexões necessárias. Cadernos do CNLF, Rio de Janeiro, CiFEFiL, v. XV, no 5, t. 1, 2011. Disponível em: http://www.filologia.org.br/xv cnlf/tomo 1/90.pdf.

WARNIER, Jean-Pierre. A mundialização da cultura. Bauru: Edusc, 2000. 